研 究

\title{
リチゥムイオン二次電池用の正極極板材料の湿式分散
}

\author{
寺下敬次郎, 浅野 英也, 宮南啓 \\ 大阪府立大学大学院工学研究科, 干 599-8531 堺市学園町 1-1.
}

\section{Wet Dispersion of Positive Electrode Materials for Lithium Ion Secondary Batteries}

\author{
Keijiro Terashita, Hideya Asano and Kei Miyanami \\ Department of Chemical Engineering, Osaka Prefecture University, 1-1 Gakuen-cho, Sakai599-8531.
}

Received December 18, 2000

\begin{abstract}
SYNOPSIS
In the present study, the methods for evaluating the dispersion of positive electrode materials for Lithium ion secondary battery were examined and the operations of wet dispersion were conducted to prepare the plate which is superior in electrical resistance. First, particle size distribution and viscosity of pastes were measured. Subsequently, the coated film was prepared on the plate using the pastes and glossiness and electrical resistance of the plate were measured.

It was reconfirmed in the study that the dispersion of positive electrode materials could be evaluated by measuring glossiness and electrical resistance of coated film on the plate. It was also pointed out that glossiness and electrical resistance could be inferred by particle diameter, $D_{10}$.

Glossiness and density of coated film showed large values by high-dispersing the paste of positive electrode materials for that to have small particle size. That meant that the plate could be prepared which is superior in electrical resistance.

The preparation of pastes is extremely important to pack tightly particles for positive electrode on the plate. It was implied that the wet dispersion of particles for positive electrode determined battery characteristics.

KEY WORDS

lithium ion secondary battery, dispersion, glossiness, electrical resistance, film
\end{abstract}

\section{1 緒 轘}

電化製品の小型化・ポータブル化・コードレス化に伴い,電 源力として用いられる電池に高性能化，高容量化，軽量化お よび小型化が求められている.このような要望に対応するた めに,ニッカド電池やリチウム電池で代表される充電可能な 二次電池が注目されてきた ${ }^{1,2)}$. その中でもリチウムイオン二 次電池は高エネルギー密度，長寿命，軽量などといった特長 があるため, 今後も広範囲において重要視される。

リチウムイオン二次電池は，正極にコバルトとリチウムの 複合体，負極に炭素，電解液にリチウム塩を一般的に採用し ている. 電池特性に僈れたリチウムイオン二次電池を設計・ 製造するには，正極・負極ともその極板にそれそれの棈成材 料を高密度充填することが要求される．極板へ構成材料を高 密度充填するには，その前工程である湿式分散プロセスが重
要である.つまり，極板へ構成材料を高密度充填することが， 電池設計のキーとなる.しかしながら，構成材料の分散操作 とその評価法については，いまだ不明確である.

筆者らはリチウムイオン二次電池の構成材料の分散状態を 評価するために，塗膜の体積抵抗率や光沢度ならびに塗膜密 度などを測定し，これらの結果より，棈成材料 (正極用粒子) の分散状態を評価できることを指摘した ${ }^{3)}$.

本研究では,正極用構成材料の分散状態の評価法に対して, さらに検討し確認するために，まず，分散機の種類を変化さ せて構成材料の湿式分散操作によりペースト化を行い，ペー ストの粒度分布および粘度を測定した。つきにぺーストを用 いてアルミニウム䈃上に塗膜を形成させ，塗膜の光沢度およ び電気抵抗を測定した.これらの測定值に基づいて構成材料 の分散状態を評価するとともに, 構成材料の高密度充填につ 
いても考察を加えた.

\section{2 実験試料，装量，実験方法}

\section{1 正極極板の構成材料とその配合比}

実験に用いた正極極板用の原料とその配合比をTable 1に示 す. 正極活物質にはコバルト酸リチウム $\left(\mathrm{LiCOO}_{2}\right)$, 導電材に カーボンをそれぞれ採用した。.またアルミニウム箔上へ塗布 を容易にするたの粘度調整用の增結剤にはカルボキシメチル セルロース (CMC), さらにアルミニウム箔の曲げにより塗膜 が剥がれるのを防ぐために結着鼡 (4フッ化エチレン樹脂)を 用いた。

\section{2 混合機および分散機}

二次電池用の構成材料の混合にはプラネタリーミキサーの 一形式である万能混合擋汼機)を用いた。この擋汼機は一軸 の擋抖翼(翼形状: フック)が公転しながら自転する作用によ り，粉体混合・混練・湿式分散を行う。

摚拌混合機を用いて粉体混合・混練・湿式分散を行っても 目的とするペーストが得られにくい，あるいは再現性に問題 がある場合がある．そこで分散機によりさらにペーストを調 製することにした．実験に用いた 3 種類の分散機とその特幑 を，簡単に述べる。

(1) 高速回転型分散機

装置の概略をFig.1(a)に示す.高速回転するディスクおよび ローターに固定ディスクや固定環を接近させ，その狭い間隙 にペーストを供給して，前断力を与えることにより分散させ る装置である. 回転ディスクと固定ディスクの間隙は，回転 ディスクを移動することによって調節できる. 本研究ではク
リアランスを 3 種類変化 $(\delta=50,100,150 \mu \mathrm{m})$ させて分散操作 を行った。

(2) 解䂶型分散機

Fig.1(b)に装置の概略が示されている.側面にメッシュと呼 ばれる笠が設置されており，かつ中心部で高速回転する回転 翼がある.上部より供給されたペーストを側面部の穊に押し つけ，網と回転翼の接触・圧迫作用により，ペーストを連続 的に網で滤すような機構により分散を行う。そのため,ペー ストの分散状態は, 網の目の大きさや回転翼の回転速度に影 響される. 本研究では, 予備実験から $75 \mu \mathrm{m}$ の網を採用し, 翼 の回転速度を 3 種類変化 $(\mathrm{N}=10,15,30 \mathrm{rps})$ させて分散実験を 行った.

(3) 圧力型分散機

この装置は高圧条件 $(1.96 \sim 68.7 \mathrm{MPa})$ において, ペーストが均 質バルフを通過して低圧部へ流れる際に分散化される(Fig.1(c)). 分散化の機構は, バルブ間隙に入ったペーストの圧カエネル ギーが速度エネルギーに変換され,バルプの間隙を通過すれば 瞬間的に低速度になる。この著しい速度の低下とエネルギー 勾配により剪断・衝撃・爆発・キャビテーション作用が働き， 分散化される. 圧力を 3 種類に設定 $(P=1.96,4.96,9.81 \mathrm{MPa})$ し て分散化を行った。

2.3 混合・湿式分散および塗膜化

リチウムイオン二次電池用の正極極板作製のための混合 · 分散操作を Fig.2に示す. まず正極活物質 (コバルト酸リチウ ム), 学電材 (カーボン)を擋汼機内に仕込み，60s 乾式混合を 行う.つきに增粘㘊を添加 (全体の 2/3) して 480 s, 混練・湿 式分散する.さらに增粘剤を添加(残りの $1 / 3$ )して 1800 s, 湿

Table 1 Materials and Mixing Rate for positive plate.

\begin{tabular}{lc}
\hline Active positive electrodes (Lithium cobaltic acid) & $100 \%$ \\
Electrically conductive material (Carbon) & $3 \%$ \\
Thickner (Carboxy-methyl-cellulose) & $83.3 \%$ \\
Binder (Ethylen 4-fluoride resin) & $11.5 \%$ \\
\hline
\end{tabular}

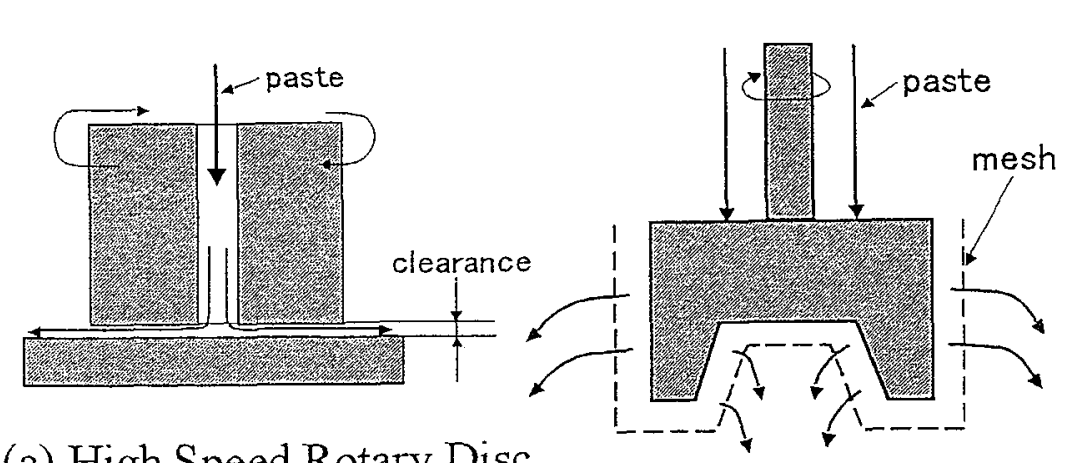

(a) High Speed Rotary Disc Disperser

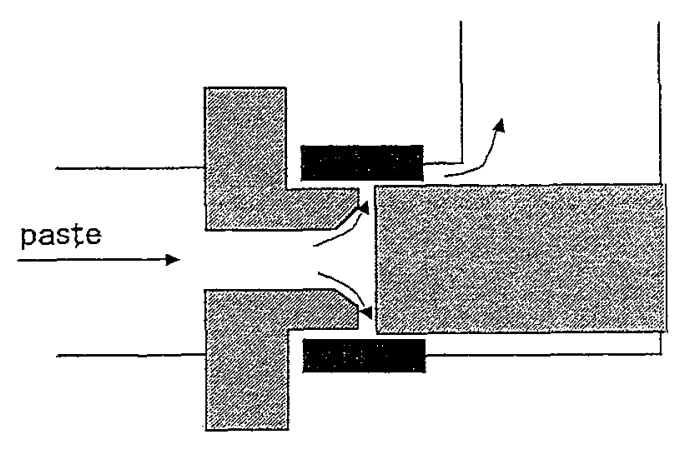

(C) High Pressure Disperser

Fig.1 Schematic diagrams of disperser used it the present study. 


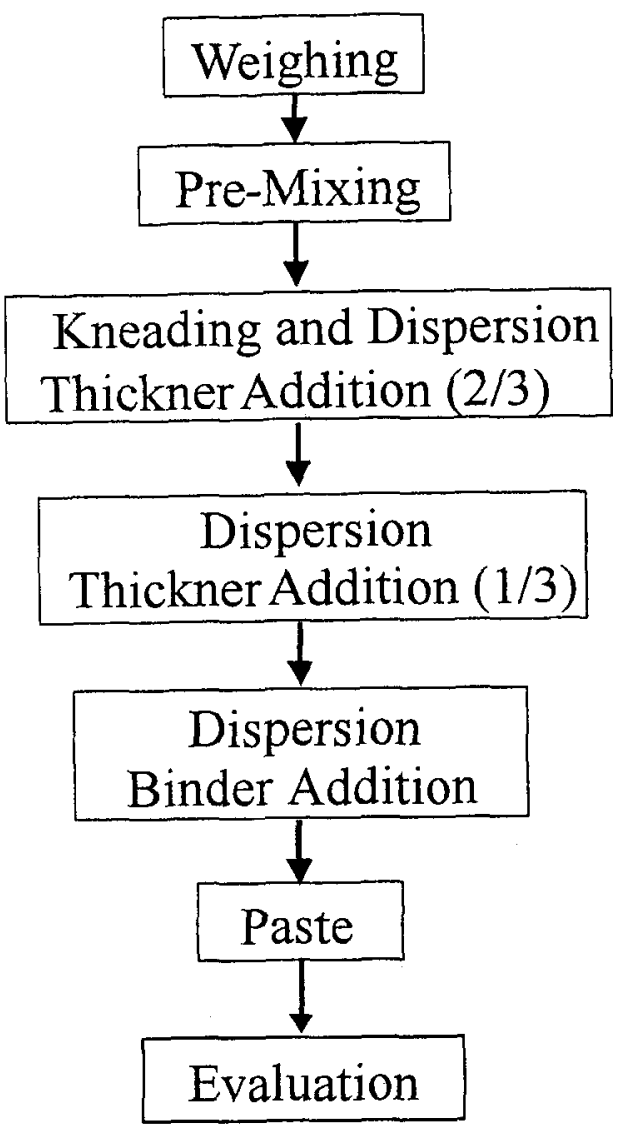

Fig.2 Flow sheet for operations of mixing and dispersion.

式分散操作を行った．最後に結着剤を加えて，さらにペース トの分散化を900s行いペーストを調製した。このようにして 得られたペーストについて評価することにした。

塗膜形成は，先述の方法で調製された正極構成材料のペー ストを用いて，アプリケーターによりアルミニウム箔(厚み $20 \mu \mathrm{m})$ 上に塗布する方法で行った ${ }^{3)}$.アプリケーターの中央部 にペーストを流し込み,アプリケーターを引くことによって， アルミニウム箔上に一定厚みのペーストを塗布する方法で 行った.つまり，リチウムイオン二次電池用の正極極板を作 製した.ここで淕膜を形成させるためのアプリケーターのク リアランス $\delta \mathrm{a}$ は $300 \mu \mathrm{m}$ であり，塗膜速度 $=$ 約 $0.038 \mathrm{~m} / \mathrm{s}$ であ る.この塗膜に注目して評価することにした。

\section{3 評価方法}

正極用構成材料のペーストの分散状態を評価するために粒 度分布および粘度測定を行った。また，淮膜に注目した分散 状態は電気抵抗および光沢度の測定結果より考察することに した。これらの湘定方法を簡単に述べることにする。

(1) ペーストの粒度分布:光回折型粒子径測定装圆にて測定し た. 粒度の積算通過分率の $10 \%$ 径 $\left(\mathrm{D}_{10}\right), 50 \%$ 径 $\left(\mathrm{D}_{50}\right), 90 \%$ 径 $\left(\mathrm{D}_{90}\right)$ およびmode径を求め，これらの結果からペースト の分散状態を考察することにした。測定される粒径が小さ ければ構成材料が高分散されていることになる.さらに粘
度は共軸二重円筒型回転式粘度計により测定した。

(2) 淦膜の光沢度 : 色や明度に関係なく, 表面の構造のみに関 係した量として取扱える鏡面光沢度を採用した。測定には 光沢度計を用いて, 入射角 85 度で測定した. 光沢度測定 は，極板を $50 \mathrm{~mm} \times 100 \mathrm{~mm}$ に切断し，塗膜を縦横 3 等分し た区域(Fig.3)，計9ケ所の光沢度を測定した。本報告の光 沢度は測定値の平均値で表されている.光沢度が大きい值 を示せば,極板表面の凹凸は小さくて塗膜が平滑化されて いることになる.つまり, 光沢度が大きい值を示せば, 構 成材料が凝集体を形成しないで,塗膜内において高分散さ れていると考えられた。

(3) 電気抵抗 : 正極極板 (塗膜) 表面上の電気抵抗は抵抗率計 により測定した.この抵抗率計は一直線上に等間隔に配列 した探針間隔 $5 \mathrm{~mm}$ のプローブ型であり，4探針法に基つ いて抵抗值が測定される.アルミニウム箔上に塗膜化して 作製された極板を $50 \mathrm{~mm} \times 100 \mathrm{~mm}$ に切断し，さらに Fig.4

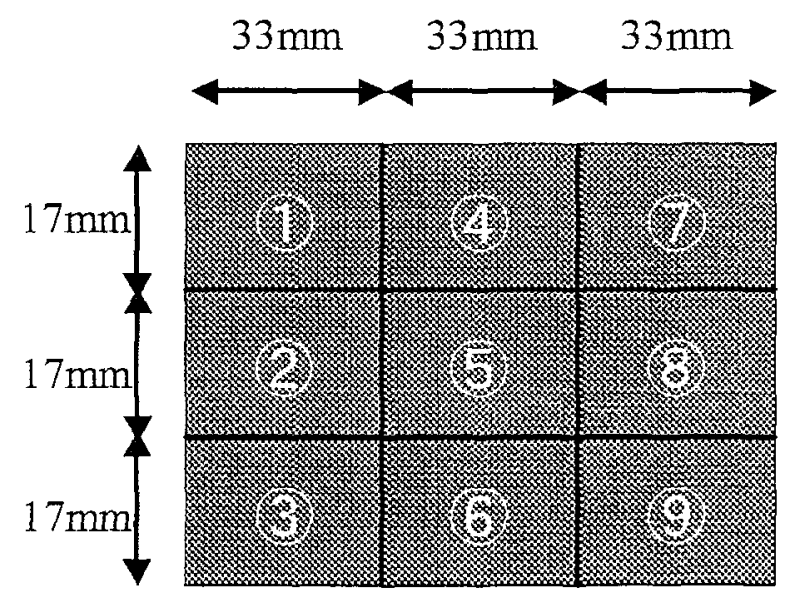

Measurement Method of Gloss Gs.

Fig.3 Spots of measurement of electrical resistance.

$20 \mathrm{~mm} 20 \mathrm{~mm} 20 \mathrm{~mm} 20 \mathrm{~mm} 20 \mathrm{~mm}$

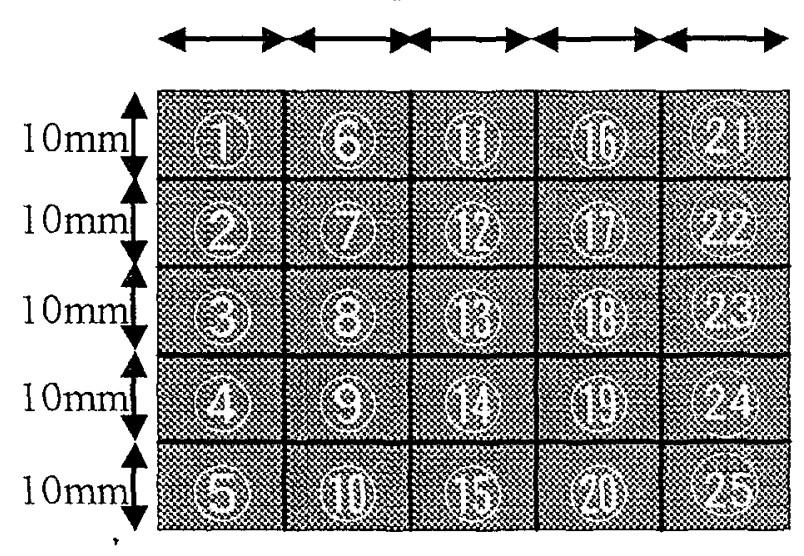

Measurement Method of Resistance

Fig.4 Spots of measurement of glossiness. 
に示すように，極板試料片を綎 5 区域×横 5 区域に区分し て, 計 25 ケ所の抵抗值を測定した.この測定值の平均值お よび変動係数より分散状態を評価することにした.本研究 における抵抗值は平均值で表現されている.勿論，抵抗值 が低いほど正極用構成材料の分散状態は良好である。

\section{4 結果および考察}

リチウムイオン二次電池の構成材料のペースト化において, 粒子径が小さければ凝集塊が少ないことを意味しているので， 正極用粒子が高分散状態にある.つまり，ペーストが高分散 であれば高密度充填状態の極板が作製できることになる。そ の結果，粒子同士の接触性がよくなることから，導電性に侵

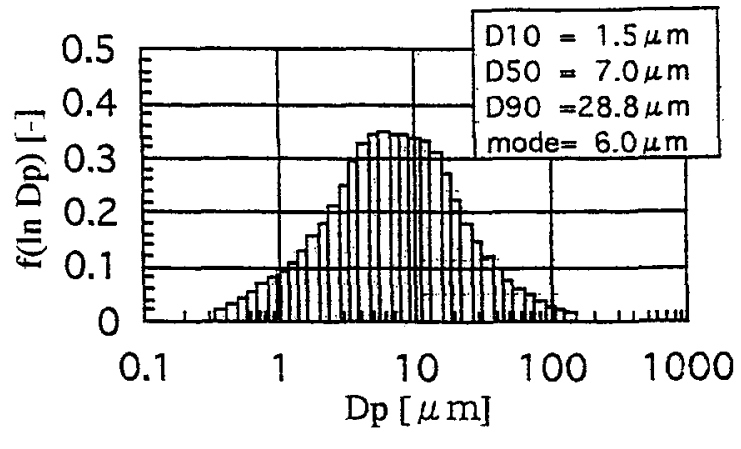

$\delta=150 \mu \mathrm{m}$
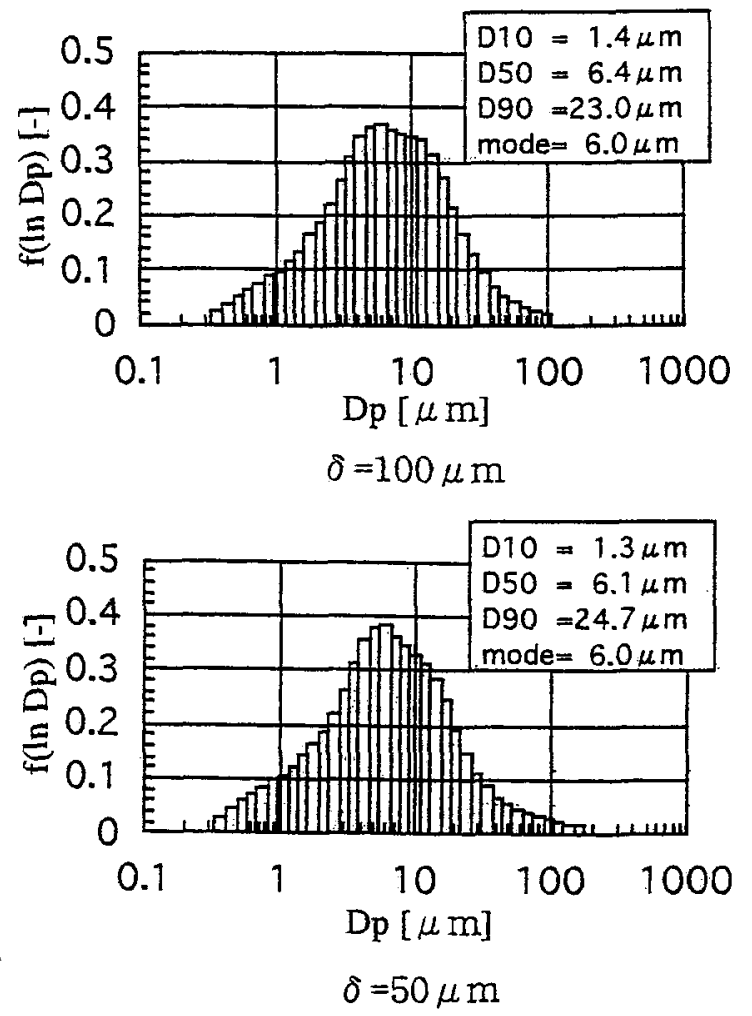

High Speed Rotary Disc Disperser

Fig.5 Frequency particle size distribution of pastes for high speed rotary disc disperser.
れると考えられた. そこで, ペーストの粒度分布ならびに極 板(塗膜)表面の光沢度および電気抵抗などを測定して, 考察 を加えることにした。

4.1 ペーストの粒度分布 (頻度分布)および粘度

3種類の分散機の操作条件を変化させてペースト化を行い， そのペーストの粒度分布を測定した. その結果を頻度分布で 表現した一例を Fig.5に示す. 同因は分散機に高速回転型を用 い，装置の主要な操作条件であるクリアランス $\delta$ を変化させ て得られた結果である. Fig.5から, 頻度分布の形状はクリア ランスを変化させても類似であることがわかった.粒径 $\mathrm{D}_{10}$ お よび $\mathrm{D}_{50}$ は，クリアランスが狭くなれば $((\mathrm{a}) \rightarrow(\mathrm{c}))$ 僅かである が小さくなるようである.つまりクリアランスが小さくなる ことにより剪断力が強く作用して，ペーストの微粒子化が幾 分行われたと解䊅された。

Fig.6には，解砕型および圧力型の分散機を用いて得られた ペーストの頻度分布の結果を示した.これらは各分散機にお いて最も微粒子化された結果である.Fig.6から，分散機の種 類が異なってもペーストの頻度分布の形状，粒径 $\mathrm{D}_{10}$ および $\mathrm{D}_{s_{0}}$ に大きな違いが見られないといえる.

以上の結果から，分散機の種類およびその操作条件が異

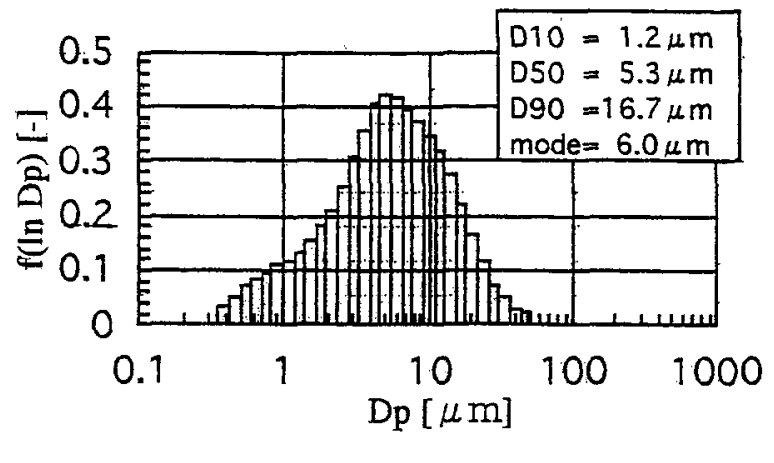

$$
r=30 \mathrm{~s}^{-1}
$$

Size-Reduced Disperser

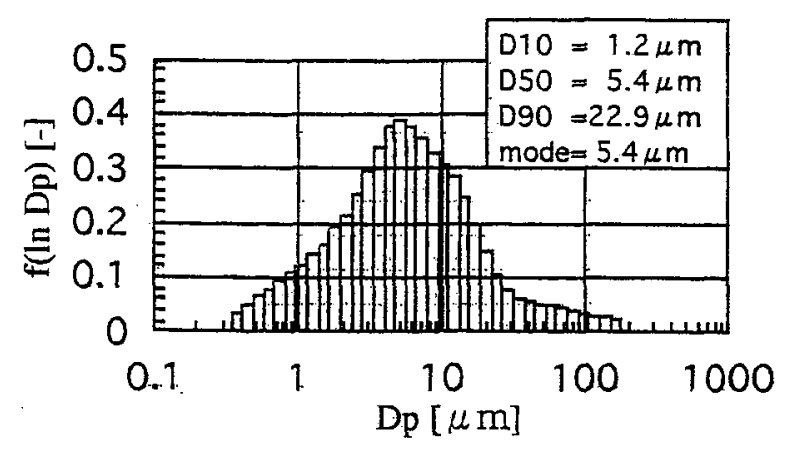

$\mathrm{P}=9.81 \mathrm{MPa}$

High Pressure Disperser

Fig.6 Frequency particle size distribution of pastes for size-reduced and high pressure disperser. 
なっても，粒径 $\mathrm{D}_{10}=1.2 \sim 1.5 \mu \mathrm{m}$ および $\mathrm{D}_{50}=5.3$ から $7.0 \mu \mathrm{m}$ の 範囲内であることかかかる。つまり，本実験に用いた構成材 料とその配合比では，粒度分布に顕著な相違が認められない ようである.しかしながら，僅かに $\mathrm{D}_{10}$ あるいは $\mathrm{D}_{50}$ に差があ るので,これらの粒径に注目して考察を行うことにした.

Fig.7に粘度係数 $\mu^{\prime}$ とペーストの粒径 $\mathrm{D}_{50}$ の関係を示す. 同 図は分散機の種類およびその操作条件を変化させて作製され たペーストの結果が併せてプロットされている。ここで粘度 係数 $\mu^{\prime}$ は分散操作後の粘度 / 分散操作前の粘度である. Fig.7 よりペーストの粘度係数は, 高速回転型分散機を採用した場 合が最も高く,ついで解砕型であり，圧力型が小さい值を示 していることがわかる.また，いずれの分散機においても粘 度は粒径 $\mathrm{D}_{s_{0}}$ が小さくなるに伴い低くなるという結果が得られ た。

以上の粘度および粒度分布の測定結果より，圧力型分散機 を用いた場合，ペーストの分散操作において最も強く剪断作 用が働いたと考えられた。

\section{2 塗膜の電気抵抗および光沢度}

分散機の種類とその操作条件を変化させてペースト化を 行った後, 淮膜(極板)を作製した. その塗膜の電気抵抗およ び塗膜表面の光沢度を測定した.これらの測定結果と 4.1)で 得られたペーストの粒径に注目して考察を加えることにする。

Fig.8に電気抵抗 $\mathrm{R}$ と平均粒子径 $\mathrm{D}_{50}$ の関係が示されている. また, Fig.9には電気抵抗值の標準偏差 $\mathrm{Sd}_{\mathrm{R}}$ と $\mathrm{D}_{50}$ の関係を示し た. Fig.8から電気抵抗が小さい值で電池特性に優れているの は,ペーストの平均粒子径が小さい場合であることがわかる. したがって,電気抵抗を良好にするには,ペーストの微粒子化 が重要である.また，電気抵抗の標準偏差が小さい値を示し ているのも $\mathrm{D}_{50}$ の小さい条件であることが認められる(Fig.9). この結果より，安定した品質の極板を作製するためにも， ペーストの微粒子化を行うことが不可欠であることがわかる.

このように電気抵抗が低くて導電性に優れた塗膜 (極板)

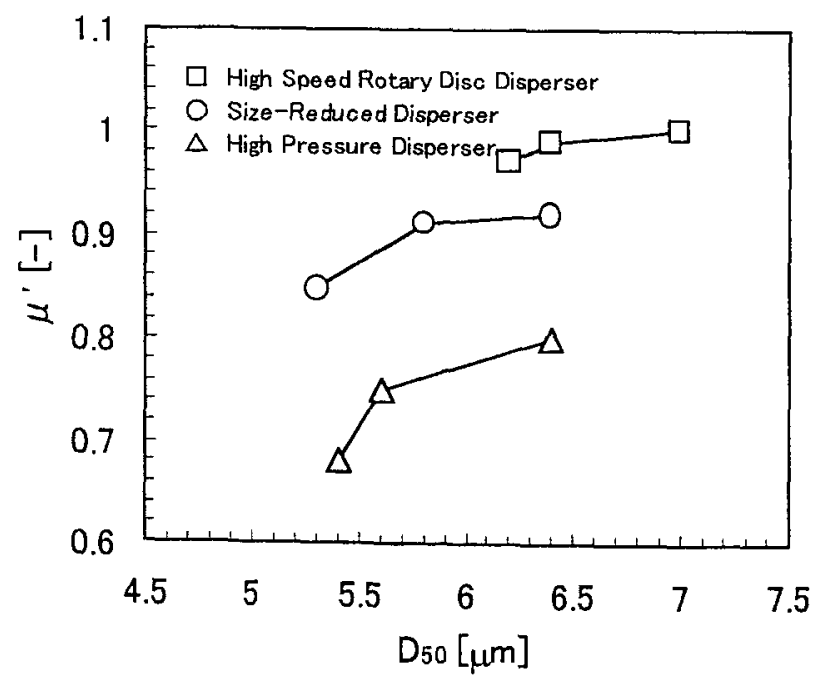

Fig.7 Relationship between viscosity factor, $\mu$ and median diameter of pastes, $D_{50}$.
は，塗膜密度の大きい条件で得られることがわかっている3). 滁膜密度が大きいことは，正極用粒子が塗膜内に高密度充填 されていることになる。

Fig.10に塗膜の光沢度 $\mathrm{Gs}$ と平均粒子径 $\mathrm{D}_{50}$ の関係を示した. 光沢度の高い塗膜はペーストのD $\mathrm{s}_{0}$ が小さい場合である.つま り構成材料の凝集体がなく，しかも微粒子化されている条件 において，塗膜の光沢度が大きい值を示すことになる．粒径 $\mathrm{D}_{10}$ が小さくて光沢度が大きい值を示せば, 湬膜密度が大, つ まり正極用粒子は高密度充填状態にある結果が得られている3).

粒径 $\mathrm{D}_{10}$ および光沢度 $\mathrm{Gs}$ と電気抵抗 $\mathrm{R}$ の関係が Fig.11に示 されている. 電気抵抗が低くて導電性に優れている極板 (塗膜) は, ペーストが微粒子化され(粒径 $\mathrm{D}_{10}$ が小), しかも埄膜の

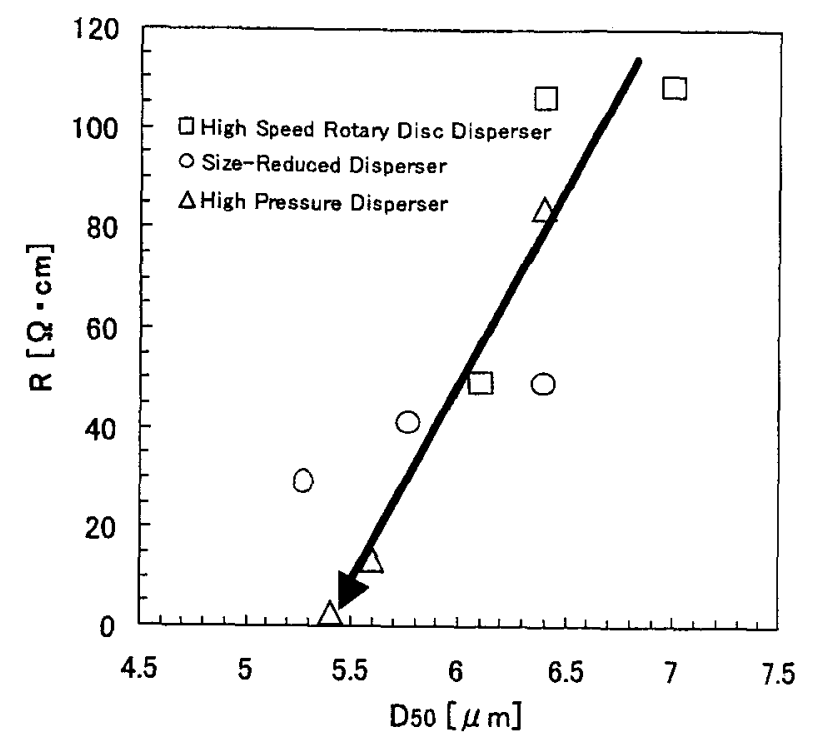

Fig.8 Relationship between electrical resistance, $R$ and median diameter, $\mathbf{D}_{50}$.

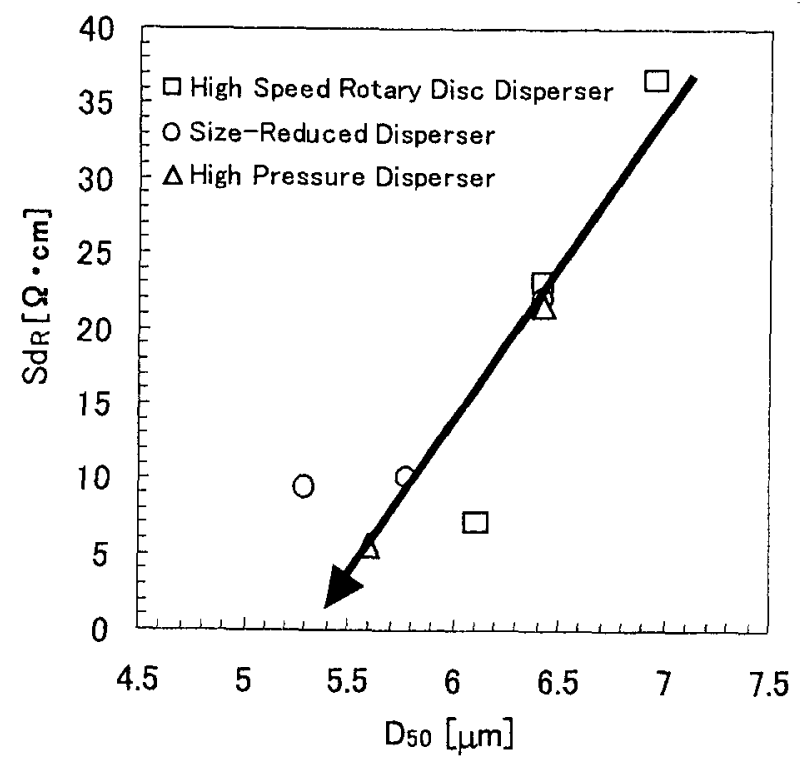

Fig.9 Relationship between standard deviation of measured value of electrical resistance, $\mathrm{Sd}_{\mathrm{R}}$ and median diameter, $\mathrm{D}_{50}$. 


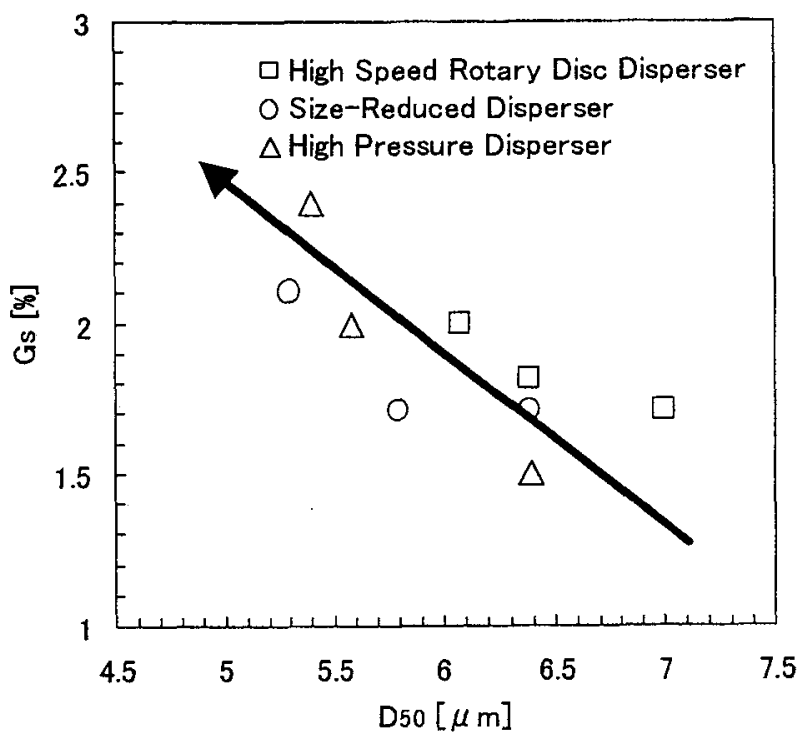

Fig.10 Relationship between glossiness of coated film, Gs and median diameter, $\mathrm{D}_{50}$.

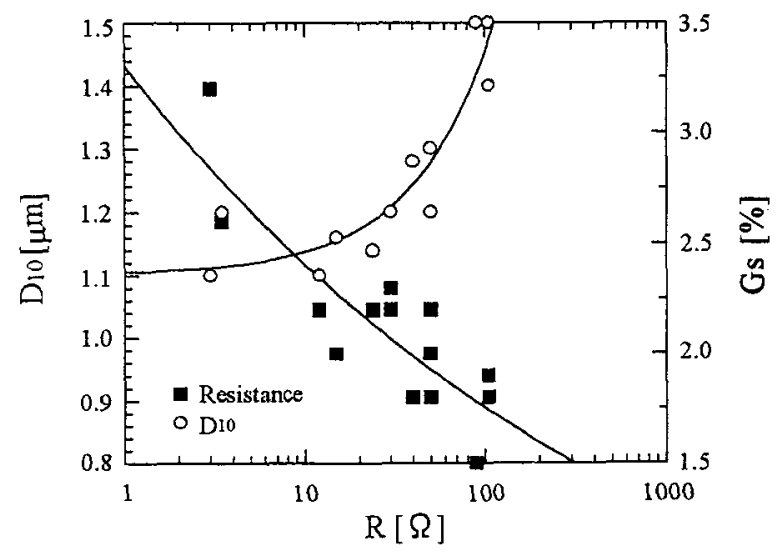

Fig.11 Relationship between diameter, $D_{10}$, glossiness, $G$ s and electrical resistance, $\mathbf{R}$.

光沢度が大きい值を示す条件において作製されることが明ら かになった。

Fig.12に粒度分布・光沢度・電気抵抗の測定結果などと極板 の関係を模式的に示した.ペーストが小粒子径になれば構成 材料が高分散されていることから,整膜の光沢度は高くなり， しかも淘膜密度が大きな值を示す.つまり，高密度充填状態 の極板を作製することができる．その結果，構成材料同士の 接触性に優れるので，電気抵抗が小さい值を示し導電性がよ くなることになる.これらの結果および考察より，塗膜化の 前工程である構成材料のペーストの調製プロセス，つまり湿 式分散操作が正極極板の充填密度および電池特性を決定づけ ることがわかった。

\section{5 結 論}

(1) ペーストの粒度分布，梁膜 (極板) の光沢度および電気抵

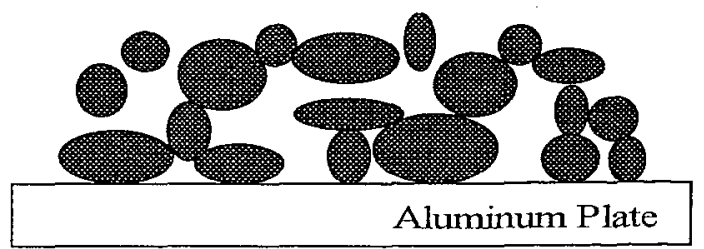

Particle Diameter Big

Dispersion Pore

Glossiness Small

Density of Film Small

Resistance Big

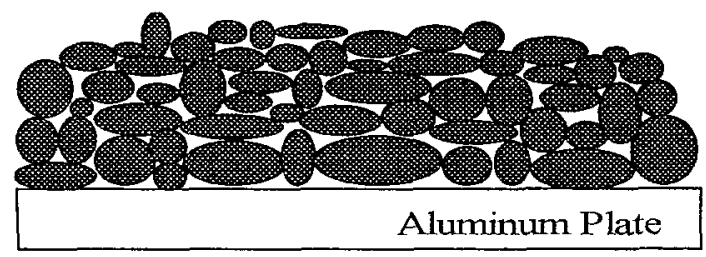

$\begin{array}{cc}\text { Particle Diameter } & \text { Small } \\ \text { Dispersion } & \text { Good } \\ \text { Glossiness } & \text { Big } \\ \text { Density of Film } & \text { Big } \\ \text { Resistance } & \text { Small }\end{array}$

Fig.12 Relationship between schematic diagrams of plate and results of measurement of physical properties.

抗を測定し,これらを関係づけて考察することにより,リ チウムイオン二次電池の正極用構成材料の分散状態が評価 できることを再確認した．また粒径 $\mathrm{D}_{10}$ および $\mathrm{D}_{50}$ より光 沢度および電気抵抗が考察できることを指摘した。

(2) 構成材料のペーストが小粒子径になるように高分散すれ ば, 塗膜の光沢度が高くなり, しかも㳂膜密度は大きな值 を示す.つまり, 高密度充填状態の漼膜を形成することが できる.高密度充填にすることができれば, 電気抵抗に優 れた極板が作製されていることになる.

(3) 極板にリチウムイオン二次電池の正極用粒子を高密度充填 するには，極板作製の前工程であるペースト調製が極めて 重要であることを明らかにした.つまり, 正極用粒子の湿 式分散操作か，電池特性を決定することを示唆した。

\section{文献}

1) 竹原善一郎監修: 高密度りチウム二次電池, テクノシステ $\Delta,(1998)$.

2) 日本電池株式会社編 : 最新実用二次電池一第 2 版, 日刊工 業新聞社, (1999).

3) 寺下敬次郎, 浅野英也, 宮南啓: "リチウムイオン二次電池 用の極板材料の混練·分散操作とその評価", 粉体および粉 末治金, 47(2000)97-102.

4) 寺下敬次郎, 宮南啓, 坂本和徳: "磁性塗膜形成とメタル粒 子の表面改質効果",粉体および粉末冶金, 40(1993)859-862. 